\title{
Down and out: acquired oculomotor nerve palsy
}

\author{
Rohan Bir Singh, ${ }^{01,2}$ Sukhman Shergill, ${ }^{3}$ Kanwar Partap Singh, ${ }^{4}$ Sahil Thakur ${ }^{2}$
}

'Ophthalmology, Harvard Medical School, Boston, Massachusetts, USA ${ }^{2}$ Ophthalmology, Government Medical College and Hospital, Chandigarh, India

${ }^{3}$ Anesthesiology, Yale-New Haven Hospital, New Haven, Connecticut, USA

${ }^{4}$ Dayanand Medical College \& Hospital, Ludhiana, Punjab, India

Correspondence to Dr Rohan Bir Singh, dr.rohandhaliwal@gmail.com and Dr Sahil Thakur, drsahilthakur@gmail.com

Accepted 27 July 2019
Check for updates

(C) BMJ Publishing Group Limited 2019. No commercial re-use. See rights and permissions. Published by BMJ.

To cite: Singh RB, Shergill $S$, Singh KP, et al. BMJ Case Rep 2019;12:e231485. doi:10.1136/bcr-2019231485

\section{DESCRIPTION}

A 50-year-old male presented to the ophthalmology emergency room with a complaint of sudden drooping of his left eyelid and double vision in the left eye (figure 1). The patient had a history of diabetes mellitus for the past 9 years. The records showed that he was poorly compliant to the prescribed oral hypoglycaemics. The patient did not report any history of recent headache associated with the presentation.

On orbital and adnexal examination, there was exotropia with hypotropia and findings typically suggestive of oculomotor (isolated third cranial nerve) palsy in the left eye. The cover test revealed that the patient could not adduct (figure 1A,D), supraduct (figure 1B) or infraduct (figure $1 \mathrm{G}, \mathrm{H}$ ) his left eye. The patient could perform lateral rotation (figure 1C,F and I) and depression (figure $1 \mathrm{H}, \mathrm{I}$ ), as well as abduct his left eye (figure 1C,F and I), thus confirming functional trochlear and abducens nerve, respectively. The pupil of the left eye had sluggish reaction to direct light and measured $4 \mathrm{~mm}$, compared with $3 \mathrm{~mm}$ in the right eye with a normal reaction to light (figure $1 \mathrm{E}$ ). The patient's visual acuity was $6 / 9$ in both eyes. The remaining cranial nerves were intact, and there was no evidence of sensory or motor weakness. The right eye was pseudophakic, and the left eye had immature senile cataract (Nuclear Sclerotic Cataract-II with Posterior Sub-capsular Cataract). The patient's posterior

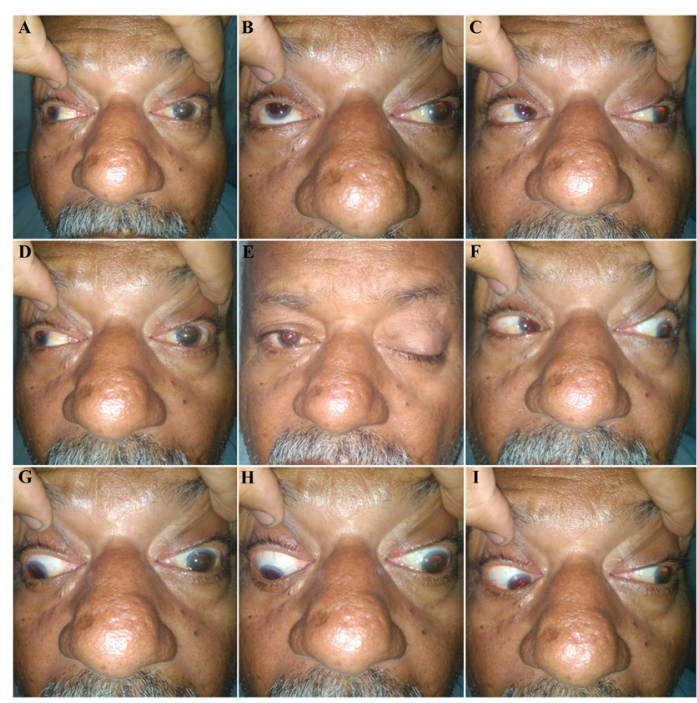

Figure 1 The patient presented to the ophthalmology emergency room with a complaint of inability to adduct $(A, D)$, infraduct $(B)$ or supraduct $(G, H)$ his left eye, thus resulting in diplopia, and sudden onset ptosis (E) of his left eyelid. The montage shows the position of the left eye in comparison to the right eye while examining the different cardinal positions of gaze. segment examination was grossly normal, and there were no signs of diabetic retinopathy.

CT and gadolinium-enhanced brain MRI scans with contrast were essentially normal. There was no evidence of intracerebral aneurysm, and this was confirmed by magnetic resonance angiography of the head and neck.

A series of blood tests showed raised blood sugar (between 330 and $350 \mathrm{mg} / \mathrm{dL}$ ), and glycated haemoglobin A1c to be $12.2 \%$. The patient was diagnosed with third nerve palsy secondary to diabetes caused by pathological microvascular ischaemia. The patient was advised strict glycaemic control. A comprehensive management plan was prepared with the opinion of an endocrinologist. The patient was prescribed basal-bolus insulin therapy that involved administering long-acting, basal insulin twice daily in combination with a rapid-acting insulin analogue injected before every meal.

The patient's hyperglycaemia was controlled to $180-200 \mathrm{mg} / \mathrm{dL}$ at his first-month follow-up. The patient made a complete recovery from the palsy. No exotropia or hypotropia was observed, and he could adduct, infraduct or supraduct his left eye well. He did not have residual ptosis of the left eye as well.

Cranial nerve neuropathies are rare long-term complications of type II diabetes mellitus, and the prevalence depends on the severity as well as duration of hyperglycaemia. Different studies

\section{Learning points}

- The patients with a long history of uncontrolled diabetes mellitus should be counselled thoroughly and informed about the consequences of persistently high blood sugar, specifically catastrophic outcomes like cranial nerve palsies.

- A high clinical suspicion, detailed history taking and clinical examination should be performed to rule out different causes of cranial nerve neuropathy such as arterial aneurysms and space-occupying lesions.

- The use of neuroimaging, that is, gadoliniumenhanced MRI, is necessary for a conclusive diagnosis, before initiating the management plan for the patient.

- Aggressive control of hyperglycaemia by ensuring compliance through close monitoring of the patient is necessary. In a majority of cases of oculomotor nerve palsy due to diabetes, the symptoms resolve if the patient is compliant and successfully control the blood sugar levels. 
have shown about $0.75 \%-1 \%$ of patients with diabetes mellitus eventually develop cranial nerve neuropathy. ${ }^{12}$ The commonly encountered cranial mononeuropathies secondary to diabetes involve cranial nerves III (oculomotor), VI (abducens) and IV (trochlear). ${ }^{3}$ Among the patients with mononeuropathies, it has been reported that oculomotor nerve palsy secondary to diabetes occurs in $11 \%$ patients. ${ }^{4}$ Typically, the palsy occurs as a result of microvasculopathy from uncontrolled hyperglycaemia.

Contributors RBS and ST diagnosed and managed the patient and authored the manuscript. KPS and SS performed the imaging and edited the manuscript.

Funding The authors have not declared a specific grant for this research from any funding agency in the public, commercial or not-for-profit sectors.
Competing interests None declared.

Patient consent for publication Obtained.

Provenance and peer review Not commissioned; externally peer reviewed.

\section{REFERENCES}

1 Watanabe K, Hagura R, Akanuma Y, et al. Characteristics of cranial nerve palsies in diabetic patients. Diabetes Res Clin Pract 1990;10:19-27.

2 Greco D, Gambina F, Pisciotta M, et al. Clinical characteristics and associated comorbidities in diabetic patients with cranial nerve palsies. J Endocrinol Invest 2012:35:146-9.

3 Urso DL, Formaro L, Scattarella L, et al. [Sixth cranial nerve palsy associated with diabetes mellitus: a case report]. Recenti Prog Med 2011;102:20-2.

4 Keane JR. Third nerve palsy: analysis of 1400 personally-examined inpatients. Can J Neurol Sci 2010;37:662-70.

Copyright 2019 BMJ Publishing Group. All rights reserved. For permission to reuse any of this content visit

https://www.bmj.com/company/products-services/rights-and-licensing/permissions/

BMJ Case Report Fellows may re-use this article for personal use and teaching without any further permission.

Become a Fellow of BMJ Case Reports today and you can:

- Submit as many cases as you like

Enjoy fast sympathetic peer review and rapid publication of accepted articles

Access all the published articles

Re-use any of the published material for personal use and teaching without further permission

\section{Customer Service}

If you have any further queries about your subscription, please contact our customer services team on +44 (0) 2071111105 or via email at support@bmj.com.

Visit casereports.bmj.com for more articles like this and to become a Fellow 